Egyptian Journal of Rabbit Science, 27 (1): 131- 148(2017)

\title{
EFFECT OF ALTERNATED DRINKING SALINE WELL WATER ON THE REPRODUCTIVE PERFORMANCE OF RABBITS
}

\author{
A.S.Morsy'; Manal, M. H. Gad - El-Moula ${ }^{2}$; Dooa, O. A. Othman ${ }^{2}$; Hassan M . \\ Sobhy ${ }^{3}$; Nagwa A. Ahmed ${ }^{4}$ \\ ${ }^{1}$ Animal and Poultry Physiology Dept., Desert Research Center, Egypt. \\ ${ }^{2}$ The Central Laboratory for Agricultural Climatic, Research Center, Egypt. \\ ${ }^{3}$ Instutute of African Research and Studies, Cairo University, Egypt. \\ ${ }^{4}$ Animal Production Dep. Fac. of agric., Cairo University, Egypt.
}

This work aimed to study the influences of drinking saline well water and the alternation with fresh tap water every week as one of the bio-stimulation methods to reduce the harmful effects of continuous drinking saline water on reproductive performance of rabbits.

A total number of $48 \mathrm{~V}$-Line rabbits old 5 months (30 does, body weight of $2955.0 \pm 32.6 \mathrm{~g}$ and 18 bucks, body weight of $2850.0 \pm 31.2$ g) were used in this study. Rabbits were randomly divided into three equal groups (10 does and 6 bucks / group). Rabbits of the $1^{\text {st }}$ group (G1) considered as control group drank tap water (301 ppm total dissolved solids, TDS), rabbits of $2^{\text {nd }}$ group (G2) drank well water (5568 ppm TDS), while rabbits of $3^{\text {rd }}$ group (G3) drank well water followed with drank fresh tap water every week until the end of experiment (alternated system).

The results showed that, conception rate was found to be higher $(P<0.05)$ in the does of $G 3(+21 \%)$ than that in the does of $G 2$. Moreover, does of G3 has insignificant decrease in the number of services per conception by - $10 \%$ compared to the does of G2. Does of $G 3$ had higher $(P<0.05)$ litter traits when compared to the does of $G 1$ and G2. On the other hand, overall mortality rate was significantly increased in the does of $G 2(26.5 \%)$ as compared to the does of $G 1(10.3 \%)$. Daily water intake was increased $(P<0.05)$ in rabbits of $G 2$ and $G 3$ as compared to the rabbits of G1. Efficiency index and feed conversion were significantly improved in the rabbits of G3 when compared to the rabbits of G1 and G2. Moreover, The cost of feeding for producing one $\mathrm{kg}$ live weight was decreased $(P<0.05)$ in does of $G 3$ by 4.08 and 2.40 L.E. as compared to the rabbits of $G 2$ and $G 1$, respectively. 
On the other hand, bucks of $G 2$ exhibited a decrease $(P<0.05)$ in ejaculate volume (29.3\%) as compared to the bucks of T3. Sperm concentration, total sperm output, total motile sperm and semen quality were significantly decreased in the bucks of G2 as compared to the bucks of G1. Sperm motility was decreased $(\mathrm{P}<0.05)$ in the bucks of G2 as compared to other groups. Also, bucks of G2 showed significantly increased in dead spermatozoa, sperm abnormalities and hydrogen ion $(\mathrm{pH})$ as compared to other two treatments. Bucks drank saline water (G2) had significant increase in reaction time as compared to the bucks of G1 and G3. However, bucks of G2 had insignificantly decreased testosterone hormone by 36.9 and $32.5 \%$ as compared to the bucks of G1 and G3, respectively.

Conclusively, applying alternating water system as a biostimulation method could eliminate the drastic effects of continuous drinking saline well water on reproductive performance of rabbits under new reclaimed lands.

Key words: Rabbits, saline well water, reproductive performance, semen quality, testosterone hormone.

Water is the most important nutrient for livestock. It is second to oxygen as immediately essential for life. The quality and quantity of drinking water may affect feed consumption and rabbit health (Sandford, 1996). Moreover, he added that water salinity is the major factor determining the suitability of particular water source for livestock. Certain salts and gases in solution make water more palatable, if not present in excess, while various salts may reduce water palatability and may be toxic at high levels Rabbits can lose nearly all the fat and more than half of protein from their bodies and still remain alive, but a loss of one tenth of body water will result in death. Furthermore, rabbits can live for a relatively long time without solid food, but lack of water produces very quick harmful effects.

The highest acceptable concentrations of total soluble salts in rabbit drinking water may be less than $3000 \mathrm{ppm}$. Using the water containing high levels of soluble salts (more than $3000 \mathrm{ppm}$ ) as the sole source of drinking water reduces rabbit performance and such effects become more apparent in summer hot season. Diminishing the high levels of salinity in drinking water could be carried out by dilution with fresh water when it is available or by elimination of the soluble salts from the drinking water (Marai et al., 2010). 


\section{EFFECT OF ALTERNATED DRINKING WELL WATER ON RABBITS 133}

Several trials have been conducted to study the effect of utilizing natural saline water on different animals (Challies et al., 1987 on cattle; Balnave and Yoselewitz, 1988 on poultry; Ayyat et al., 1991; Ahmed, 1996; Ahmed and Abdel-Rahman, 2004; Marai et al., 2005 and Morsy et al., 2016 on rabbits). However, rabbits received a little attention in this respect although they are considered as a useful contribution to the meat supply in developing countries, which suffer from animal protein shortage. Ahmad and Abdel-Rahman (2004) confirmed that Baladi, Bouscat and California breed rabbits, could tolerate the salinity of normal saline well-water $(2980 \mathrm{ppm})$ without deterioration effects either on reproductive performance. Unfortunately, there are very few researches dealt with how to overcome the problems of drinking high levels of salinity of drinking water in rabbits.

Many factors affect semen quality, genetic, environment, management, and physiological factors aspects normal spermatogenesis, sperm function and male fertility (García-Tomas et al., 2008). Exposure of buck rabbits to saline drinking water delayed mating desire/ability and decreased semen quality and leydig cell function (Veeramachaneni et al., 2001) in human. Also, El-Darawany and Farghaly (1995) and Abd El- Razik et al. (1999) found that libido in buck rabbits and all semen characteristics were negatively affected with drinking agriculture drainage water for 3 - 7 months compared to drinking tap water. Few studies were concerned with the effect of drinking saline water on reproduction of male rabbits. Therefore this experiment aimed to study the influences of drinking saline well water and the alternation with fresh tap water every week as one of the bio-stimulation methods to reduce the harmful effects of continuous drinking saline water on reproductive performance of doe and buck rabbits.

\section{MATERIALS AND METHODS}

The present study was carried out in a private rabbit's farm at CairoOasis high way, about $60 \mathrm{~km}$ South West Cairo from September 2013 up to February 2014. The laboratory work was executed in Lab of Animal Production Research Institute, Ministry of Agriculture, Cairo, Egypt and in in the Labs belonging to Egyptian-Spanish Project titled "Raise the level of low income families and activate the role of woman in community development through the use of modern technologies in the project of Rabbits in Egypt", Faculty of Agriculture, Cairo University in Research Park. 
The study aimed to determine the influences of drinking saline well water and the alternation with fresh tap water every week as one of the biostimulation methods to reduce the harmful effects of drinking saline water on reproductive performance of rabbits.

A total number of $48 \mathrm{~V}$-Line rabbits old 5 months (30 does, body weight of $2955.0 \pm 32.6 \mathrm{~g}$ and 18 bucks, body weight of $2850.0 \pm 31.2 \mathrm{~g}$ ) were used in this study. Rabbits were randomly divided into three equal treatments (10 does and 6 bucks / group). Rabbits of the $1^{\text {st }}$ group (G1) considered as control group drank tap water (301 ppm TDS), rabbits of $2^{\text {nd }}$ group (G2) drank well water (5568 ppm TDS), while rabbits of $3^{\text {rd }}$ group (G3) drank well water followed with drank fresh tap water every week until the end of experiment (alternated system as a biostimulation method). Well and tap water were chemically analyzed (Table 1) according to Muller (1995).

Table 1. Chemical analysis of well water and tap water samples.

\begin{tabular}{lcc}
\hline Chemical analysis & Well water & Tap water \\
\hline Total dissolved salts $(\mathrm{Dacisamenz} / \mathrm{m})$ & 6.9 & 0.47 \\
Electric conductivity (ds/m) & 5568.0 & 301.0 \\
Hydrogen ion $(\mathrm{pH})$ & 7.8 & 7.6 \\
\hline Dissolved anions $($ Mellimka / 1L): & & \\
Carbonates & - & - \\
Bicarbonate & 2.0 & 0.5 \\
Chloride & 40.2 & 3.5 \\
Sulphates & 25.1 & 0.68 \\
\hline Cations dissolved (Mellimkavii / $)$ & & \\
Calcium & 23.0 & 1.5 \\
Magnesium & 16.2 & 0.5 \\
Sodium & 26.1 & 3.5 \\
Potassium & 0.13 & 0.13 \\
Residual sodium carbonate & - & - \\
Ratio of sodium adsorbed & 5.9 & 2.5 \\
\hline
\end{tabular}

Rabbits were fed, ad-libitum, a commercial concentrate pelleted diet containing $18.0 \%$ crude protein, $16.3 \%$ crude fiber, $2.5 \%$ fat, $0.6 \%$ minerals mixture and $2730 \mathrm{kcal} / \mathrm{kg}$ digestible energy according to NRC (1977). Water was made available all day through nipples drinker system.

Blood samples were taken from marginal ear vein into EDETA tubes. The rest of the blood was centrifuged for 15 minutes of $3000 \mathrm{rpm}$ to 
collect plasma before being stored at $-20^{\circ} \mathrm{C}$ until testosterone hormone analysis by radioimmunoassay (RIA) method.

Reproductive traits were measured as follows:

Conception rate $(\%)=\underline{\text { Number of conceived does from the first service }} \times 100$

Total number of served does

Number of services per conception=Number of services required for conception

Number of conceived does

Gestation period $($ day $)=$ Period elapsed from conception till parturition.

Litter size $=$ Total number of born bunnies (Born stillbirth + Viable bunnies).

Litter weight $=$ Recorded from birth till weaning (4 weeks age).

Stillbirth $(\%)=$ Number of stillbirth bunnies $\times 100$

Total number of born bunnies

Pre-weaning mortality $(\%)=$ Litter size at birth - litter size at weaning $\times 100$

Litter size at birth

Overall of mortality rate $(\%)=$ Stillbirth $(\%)+$ Pre-weaning mortality $(\%)$.

Daily feed intake, daily water intake and total feed intake were measured.

Productive efficiency index $(\mathrm{kg}$, live weight $)=$ Litter size at weaning $\times$

Number of parities $\times$ Total weaning weight $(\mathrm{kg})$.

Cost of feed for producing $1 \mathrm{Kg}$ live weight of rabbit $=$ Feed conversion $\times$ Price of $1 \mathrm{~kg}$ feed.

Feed conversion $=$ Total feed intake $(\mathrm{g}) /$ Total body gain $(\mathrm{g})$

Semen was collected (three times during experimental period) from 6 bucks/group using a clean, dried and sterilized standard artificial vagina of rabbits and a teaser doe according to (Mocé et al., 2000). Reaction time was calculated in seconds as the time from introducing the doe to the buck and incidence of complete intercourse and ejaculation using stopwatch (Luzi et al., 1996). The ejaculate volume was measured using a graduated collection tube after gel mass removal. Sperm concentration was determined by the haemocytometer according to (Smith and Mayer, 1955). Total sperm output was calculated by multiplying ejaculate volume and spermatozoa concentration. Percentage of live and abnormal sperms were determined after staining with eosine and nigrosine (Blom, 1950) and then calculated as a percentage out of randomly chosen 100 sperm counted. Percentage of motile sperm was estimated a phase-contrast microscope according to (Melrose and Laing, 1970). Total number of motile sperm (TMS) was calculated by multiplying percentage of motile sperm and total sperm output.

Semen quality factor $(\mathrm{SQF})=($ Sperm concentration $\times$ Ejaculate volume $\times$ Live spermatozoa) $/ 100$. 
Hydrogen ion concentration $(\mathrm{pH})$ of semen was determined immediately after collection using $\mathrm{pH}$ paper.

Data was analyzed by the least square analysis of variance using the General Linear Model Procedure (SAS, 2004). The design was one way analysis and the model was as follows:

$$
Y_{i j}=\mu+\operatorname{Tr}_{i}+e_{i j}
$$

Where, $Y_{i j}=$ Any observation of $j^{\text {th }}$ animal within $i^{\text {th }}$ group, $\mu=$ Overall mean, $\operatorname{Tr}_{\mathrm{i}}=$ Effect of $\mathrm{i}^{\text {th }}$ group (i: $\left.1-3\right), \mathrm{e}_{\mathrm{ij}}=$ Experimental error.

Duncan Multiple Range Test (Duncan, 1955) was used to test the level of significance among means.

\section{RESULTS AND DISSCUTION}

\section{1- Doe reproductive performance}

Conception rate was found to be higher $(\mathrm{P}<0.05)$ in the does of $\mathrm{G} 3$ (rabbits alternated drank well water with tap water every week) by about $21.1 \%$ than that in G2 (rabbits drank saline well water). Furthermore, the conception rate of G3 exceeded their counterparts of control group by about $7.4 \%$ with insignificant differences.

On the other hand, does of G3 have insignificant decrease in number of services per conception (9.6\%) compared to G2 (Table 2). Improvement of the conception rate in does of G3 may be due to that alternated drank saline water with tap water washed the excess ingestion minerals that may realized the maintenance in mineral balance and consequently improved the reproductive performance of doe.

The ingestion of well water leads to changes in the retention and excretions of minerals and may change mineral balance (Marai and Habeeb, 1994). So, maintenance of mineral balance in animals is important for the rabbit production and reproductive performance (Marai et al., 2010).

Minerals play a significant role in many aspects of production and reproduction including successful establishment of pregnancy and conception rate. Minerals activate enzymes; which are essential co-factors of metabolic reactions function as carriers of proteins, regulate digestion, respiration, water balance, muscle reaction, nerve transmission and skeletal strength (Haenlein, 1991).

Concerning the gestation length, the present findings revealed that there were no significantly differences among all treatments (Table 2). 
Table 2. Reproductive performance of V-line doe rabbits as affected by drinking saline well water.

\begin{tabular}{lccc}
\hline Items & \multicolumn{3}{c}{ Treatment groups } \\
\cline { 2 - 4 } & G1 & G2 & G3 \\
\hline Conception rate $(\%)$ & $66.6^{\mathrm{ab}} \pm 3.7$ & $61.1^{\mathrm{b}} \pm 1.9$ & $74.0^{\mathrm{a}} \pm 5.7$ \\
No. of services/conception & $1.56 \pm 0.07$ & $1.66 \pm 0.05$ & $1.50 \pm 0.11$ \\
Gestation period (day) & $31.7 \pm 0.21$ & $31.4 \pm 0.12$ & $31.7 \pm 0.19$ \\
\hline
\end{tabular}

$\mathrm{a}, \mathrm{b}$ Means bearing different superscripts within the same row are significantly different $(\mathrm{P}<0.05)$.

G1 (Control) = Rabbits drank tap water (301 ppm TDS); G2 =Rabbits drank saline well water (5568 ppm TDS); G3 = Rabbits alternated drank saline well water with tap water weekly.

\section{2- Litter traits}

The results in Table (3) demonstrated that does receiving alternated saline water with tap water $(\mathrm{G} 3)$ had higher $(\mathrm{P}<0.05)$ litter size at birth, litter size at weaning, litter weight at birth and litter weight at weaning by 32.7 , 23.0, 24.1 and $13.6 \%$, respectively as compared to the does drinking tap water (G1) and by about 22.2, 33.3, 19.0 and $36.0 \%$ when compared to the does of drinking saline water $(\mathrm{G} 2)$.

On the other hand, overall of mortality rate $(\%)$ of does drank well water had the highest value $(26.5 \%)$ followed by does of G3 $(16.8 \%)$ and control group (10.3\%).

These results agreed with those of (Marai et al., 2010) where litter size and weight at birth and weaning and mortality, seemed to be negatively affected with drinking high saline water (particularly $\geq 3000 \mathrm{ppm} \mathrm{NaCl}$ ) and the effects were progressive with the increase in the level of salinity. The rate of mortality directly increased as the concentration of $\mathrm{NaCl}$ increased in drinking water (Habeeb et al., 1997 and Marai et al., 2005).

This biostimulation method keep the maintenance of mineral balance and resulted in enhancing the reproduction performance of doe rabbits. The results illustrated that, litter traits significantly improved with the use of alternated natural saline well water with tap water (G3). 
Table 3. Litter traits and mortality rate of V-line doe rabbits as affected by drinking saline well water.

\begin{tabular}{|c|c|c|c|}
\hline \multirow[t]{2}{*}{ Items } & \multicolumn{3}{|c|}{ Treatment groups } \\
\hline & G1 & G2 & G3 \\
\hline Litter size at birth & $5.8^{\mathrm{b}} \pm 0.37$ & $6.3^{b} \pm 0.32$ & $7.7^{\mathrm{a}} \pm 0.48$ \\
\hline Litter size at weaning & $5.2^{\mathrm{b}} \pm 0.25$ & $4.8^{\mathrm{b}} \pm 0.29$ & $6.4^{\mathrm{a}} \pm 0.32$ \\
\hline Litter weight at birth (g) & $338.7^{\mathrm{b}} \pm 12.6$ & $353.3^{\mathrm{b}} \pm 13.6$ & $420.5^{\mathrm{a}} \pm 27.8$ \\
\hline Litter weight at weaning (g) & $2597.5^{\mathrm{b}} \pm 109.2$ & $2168.8^{\mathrm{c}} \pm 67.6$ & $2951.1^{\mathrm{a}} \pm 106.3$ \\
\hline No. of stillbirth & $0.0 \pm 0.00$ & $0.2 \pm 0.15$ & $0.0 \pm 0.0$ \\
\hline Stillbirth (\%) & $0.0 \pm 0.00$ & $2.7 \pm 1.9$ & $0.0 \pm 0.0$ \\
\hline $\begin{array}{l}\text { No. of dead bunnies, pre- } \\
\text { weaning }\end{array}$ & $0.6^{\mathrm{b}} \pm 0.18$ & $1.5^{\mathrm{a}} \pm 0.37$ & $1.3^{\mathrm{ab}} \pm 0.32$ \\
\hline Pre-weaning mortality (\%) & $10.3^{\mathrm{b}} \pm 2.4$ & $23.8^{\mathrm{a}} \pm 4.3$ & $16.8^{\mathrm{ab}} \pm 4.3$ \\
\hline Overall of mortality rate (\%) & $10.3^{\mathrm{b}} \pm 2.4$ & $26.5^{\mathrm{a}} \pm 6.4$ & $16.8^{\mathrm{ab}} \pm 4.3$ \\
\hline
\end{tabular}

$\mathrm{a}, \mathrm{b}, \mathrm{c}$ Means bearing different superscripts within the same row are significantly different $(\mathrm{P}<0.05)$.

G1 $($ Control $)=$ Rabbits drank tap water $(301$ ppm TDS $) ; \mathrm{G} 2=$ Rabbits drank saline well water (5568 ppm TDS); G3 = Rabbits alternated drank saline well water with tap water weekly.

\section{3- Offspring growth performance}

Results revealed that receiving saline water had no significantly effects on offspring growth performance (Table 4), although, does in G3 had higher bunny weight at birth and weaning in addition to higher average daily gain and relative growth rate as compared to G2 and G1 groups.

\section{4- Economical indicator}

Drinking tap water $(\mathrm{G} 1)$ associated with an increase $(\mathrm{P}<0.05)$ in daily feed intake as compared to G2 and G3 groups (Table 5). Similar trend was reported by El-Darawany et al. (1994) and Ayyat et al. (1991). Feed intake was found to be decrease gradually with the progressive increase of the salinity levels (Ayyat et al., 1991; Gad, 1996 and Marai et al., 2005). This increment in daily feed intake of G1 and G3 groups may be a result to the appetizing effect of the low levels of salinity consumed and/or alternated 
EFFECT OF ALTERNATED DRINKING WELL WATER ON RABBITS 139

Table 4. Offspring's of V-line doe rabbits as affected by drinking saline well water.

\begin{tabular}{lccc}
\hline Items & \multicolumn{3}{c}{ Treatment groups } \\
\cline { 2 - 4 } & G1 & G2 & G3 \\
\hline Bunny weight at birth $(\mathbf{g})$ & $59.1 \pm 1.8$ & $56.7 \pm 1.6$ & $54.8 \pm 2.2$ \\
Bunny weight at weaning $(\mathbf{g})$ & $510.3 \pm 29.8$ & $471.6 \pm 28.7$ & $481.0 \pm 31.7$ \\
Average daily gain $(\mathbf{g})$ & $16.1 \pm 1.0$ & $14.8 \pm 1.0$ & $15.2 \pm 1.1$ \\
Relative growth rate $(\boldsymbol{\%})$ & $157.2 \pm 1.6$ & $154.4 \pm 3.1$ & $156.2 \pm 3.5$ \\
\hline
\end{tabular}

G1 (Control) = Rabbits drank tap water (301 ppm TDS); G2 =Rabbits drank saline well water (5568 ppm TDS); G3 = Rabbits alternated drank saline well water with tap water weekly.

Table 5. Economical indicate of V-line doe rabbits as affected by drinking saline well water.

\begin{tabular}{|c|c|c|c|}
\hline \multirow[t]{2}{*}{ Items } & \multicolumn{3}{|c|}{ Treatment groups } \\
\hline & G1 & G2 & G3 \\
\hline Daily feed intake (g) & $173.7^{\mathrm{a}} \pm 6.6$ & $161.4^{\mathrm{b}} \pm 6.0$ & $166.1^{\mathrm{b}} \pm 5.2$ \\
\hline Total feed intake (kg) & $26.0^{\mathrm{a}} \pm 2.0$ & $24.2^{\mathrm{b}} \pm 1.7$ & $24.9^{\mathrm{b}} \pm 1.4$ \\
\hline Daily water intake (ml) & $211.8^{\mathrm{c}} \pm 6.1$ & $264.5^{\mathrm{a}} \pm 7.4$ & $233.0^{\mathrm{b}} \pm 7.3$ \\
\hline Efficiency index (kg, live weight) & $5.2^{\mathrm{b}} \pm 0.22$ & $4.3^{\mathrm{c}} \pm 0.13$ & $5.9^{\mathrm{a}} \pm 0.21$ \\
\hline Feed conversion & $5.0^{\mathrm{a}} \pm 0.30$ & $5.6^{\mathrm{a}} \pm 0.29$ & $4.2^{\mathrm{b}} \pm 0.27$ \\
\hline $\begin{array}{l}\text { Cost of feeding for producing } \\
1 \mathrm{~kg} \text { live weight (L.E.) }\end{array}$ & $15.0^{\mathrm{a}} \pm 0.45$ & $16.7^{\mathrm{a}} \pm 0.44$ & $12.6^{\mathrm{b}} \pm 0.41$ \\
\hline
\end{tabular}

$a, b, c$ Means bearing different superscripts within the same row are significantly different $(\mathrm{P}<0.05)$.

G1 $($ Control $)=$ Rabbits drank tap water $(301$ ppm TDS); G2 =Rabbits drank saline well water (5568 ppm TDS); G3 = Rabbits alternated drank saline well water with tap water weekly.

Total feed intake $=$ daily feed intake $\times 150$ days (experimental period). Cost of feeding for producing $1 \mathrm{~kg}$ live weight (L.E.) $=$ feed conversion $\times$ price of $1 \mathrm{~kg}$ feed (L.E. $3.0 / \mathrm{kg}$ ).

drank saline water with tap water may decrease ingestion of salts and appropriate the requirements of does and hence enhance feed intake and feed conversion (Marai et al., 2010). 
In contrary, daily water intake increased $(\mathrm{P}<0.05)$ in rabbits of $\mathrm{G} 2$ and G3 by about 25.0 and $10.0 \%$, respectively as compared to control group (G1).This result demonstrated that daily water intake was significantly increased with the use of well water which was agreement with results reported by (Amal, 2003; Ayyat et al., 1991 and Abdel-Samee \& El-Masry, 1992). The obtained results may related to the fact that drinking a high level of saline water increases the need for water used in the excretion of the most anions and cations through increasing water output saline water this behavior related to the wisdom of body for keeping health to the systematic physiology and realized body homostatsis. The animal increases its water intake through drinking a large amount of it (Baile and McLaughlin, 1987; pond et al., 1995; Guyton and Hall, 1996; Suckow \& Douglas, 1997 and Amal, 2003).

Rabbits of $\mathrm{G} 3$ improved $(\mathrm{P}<0.05)$ their efficiency index and feed conversion by 36.1 and $24.4 \%$, respectively when compared to G2 and by 14.0 and $15.9 \%$, respectively when compared to G1. Moreover, cost of feeding for producing one $\mathrm{kg}$ live weight in the rabbits of G3 decreased $(\mathrm{P}<0.05)$ by about 4.08 and 2.4 L.E. as compared to $\mathrm{G} 2$ and $\mathrm{G} 1$, respectively. This result proved that alleviating the salinity of well water by using alternation with fresh tap water every week as a biostimulation method in farms of desert area in Egypt could improve the reproductive performance of doe rabbits (Table 3, 4 and5)

\section{5- Semen quality, reaction time and testosterone hormone}

Bucks of $\mathrm{G} 2$ exhibited a decrease $(\mathrm{P}<0.05)$ in ejaculate volume by $29.3 \%$ as compared to G3 (Table 6). Sperm concentration, total sperm output, total motile sperm and semen quality factor were significantly decreased in the bucks of $\mathrm{G} 2$ by $38.9,47.8,61.9$ and $57.5 \%$, respectively as compared to G1.

Sperm motility was decreased $(\mathrm{P}<0.05)$ in the bucks of $\mathrm{G} 2$ by 26.8 and $25.8 \%$ as compared to G1 and G3, respectively. Similar trend was obtained by (Yousef et al., 2003 a \& b) in rabbits and Amal (2013) in cocks. The drastic effect of accumulate saline water intake may reflect on low semen quality and may be due to severe degeneration of testes tissue and aggregation of RBC'S in central vein and in the sinusoids, aggregation of 
EFFECT OF ALTERNATED DRINKING WELL WATER ON RABBITS 141

Table 6. Semen quality of V-line buck rabbits as affected by drinking saline well water.

\begin{tabular}{|c|c|c|c|}
\hline \multirow[t]{2}{*}{ Items } & \multicolumn{3}{|c|}{ Treatment groups } \\
\hline & G1 & G2 & G3 \\
\hline Ejaculate volume (ml) & $0.76^{\mathrm{ab}} \pm 0.05$ & $0.65^{\mathrm{b}} \pm 0.07$ & $0.92^{\mathrm{a}} \pm 0.04$ \\
\hline Sperm concentration $\left(\times 10^{6} \mathrm{ml}\right)$ & $192.5^{\mathrm{a}} \pm 23.0$ & $117.5^{\mathrm{b}} \pm 20.2$ & $140.0^{\mathrm{ab}} \pm 20.1$ \\
\hline Total sperm output $\left(\times 10^{6}\right)$ & $146.3^{\mathrm{a}} \pm 24.7$ & $76.3^{\mathrm{b}} \pm 23.3$ & $128.8^{\mathrm{ab}} \pm 20.1$ \\
\hline Sperm motility (\%) & $83.7^{\mathrm{a}} \pm 1.7$ & $61.2^{\mathrm{b}} \pm 4.5$ & $82.5^{\mathrm{a}} \pm 2.1$ \\
\hline Total motile sperm $\left(\times 10^{6}\right)$ & $122.4^{\mathrm{a}} \pm 23.1$ & $46.6^{\mathrm{b}} \pm 17.8$ & $106.2^{\mathrm{ab}} \pm 15.7$ \\
\hline Live spermatozoa (\%) & $80.6^{\mathrm{a}} \pm 0.63$ & $65.6^{\mathrm{b}} \pm 2.6$ & $83.5^{\mathrm{a}} \pm 1.0$ \\
\hline Dead spermatozoa (\%) & $19.4^{\mathrm{b}} \pm 1.6$ & $34.4^{\mathrm{a}} \pm 2.6$ & $16.5^{\mathrm{b}} \pm 1.0$ \\
\hline Sperm abnormalities (\%) & $10.0^{\mathrm{b}} \pm 0.64$ & $16.0^{\mathrm{a}} \pm 0.90$ & $9.2^{\mathrm{b}} \pm 0.81$ \\
\hline Semen quality factor & $117.9^{\mathrm{a}} \pm 20.3$ & $50.0^{\mathrm{b}} \pm 13.2$ & $107.5^{\mathrm{ab}} \pm 17.1$ \\
\hline Hydrogen ion (pH) & $6.9^{\mathrm{b}} \pm 0.02$ & $7.3^{\mathrm{a}} \pm 0.05$ & $7.0^{\mathrm{b}} \pm 0.03$ \\
\hline
\end{tabular}

$\mathrm{a}$, b Means bearing different superscripts within the same row are significantly different $(\mathrm{P}<0.05)$.

G1 $($ Control) = Rabbits drank tap water (301 ppm TDS); G2 =Rabbits drank saline well water (5568 ppm TDS); G3 = Rabbits alternated drank saline well water with tap water weekly.

lymphocytes, necrosis of tubular epithelium, severe hemorrhage, severs degeneration of the kidney tissues (Attia et al., 2015).

Lower semen quality may reflect an adverse effect of drinking saline water on the spermatogenic process by cause a stress on the pituitary gland and led to alteration in the gonadotropins releasing cells activity which controls the androgenic secretion by testes (Attia et al., 2015). They found that the long term of saline exhibited a marked reduction in the semen quality by the significant reduction in the sperm-cells concentration, percentages of alive sperm-cells and percentage of advanced motility of spermatozoa. 
Also, bucks of G2 (drinking 5568 ppm TDS) showed an increase in dead spermatozoa, sperm abnormalities and hydrogen ion $(\mathrm{pH})$ by 77.3 , 60.0and $5.3 \%$, respectively as compared to G1 and increased by 108.4, 73.9 and $4.5 \%$, respectively when compared to G3 (Table 6). The significant increase in $\mathrm{pH}$ value in $\mathrm{G} 2$ may be due to the increased percentage of dead cells. Good quality semen is usually on the acid side of neutrality than semen with lower sperm-cells concentration and semen containing many dead spermatozoa may evolve ammonia, which will increase the $\mathrm{pH}$ value (Graves, 1978). Drinking saline water for bucks resulted in an increase in the acrosomal damage which might contribute to the elevation percentage of dead and abnormal sperm (Yousef et al., 2003 a \& b and Attia et al., 2015).

Bucks drank well saline water (G2) had a significant increase in reaction time as compared to G1 and G3 groups. However, bucks of G2 had insignificantly decreased testosterone hormone by 36.9 and $32.5 \%$ as compared to G1 and G3 groups, respectively (Figure 1, A and B). This decrease in libido as a result of drinking high level of saline well water may be due to the decrease in testosterone level and leydig cell function (El-Darawany and Farghaly, 1995; Veeramachaneni et al., 2001 and Attia et al., 2015).
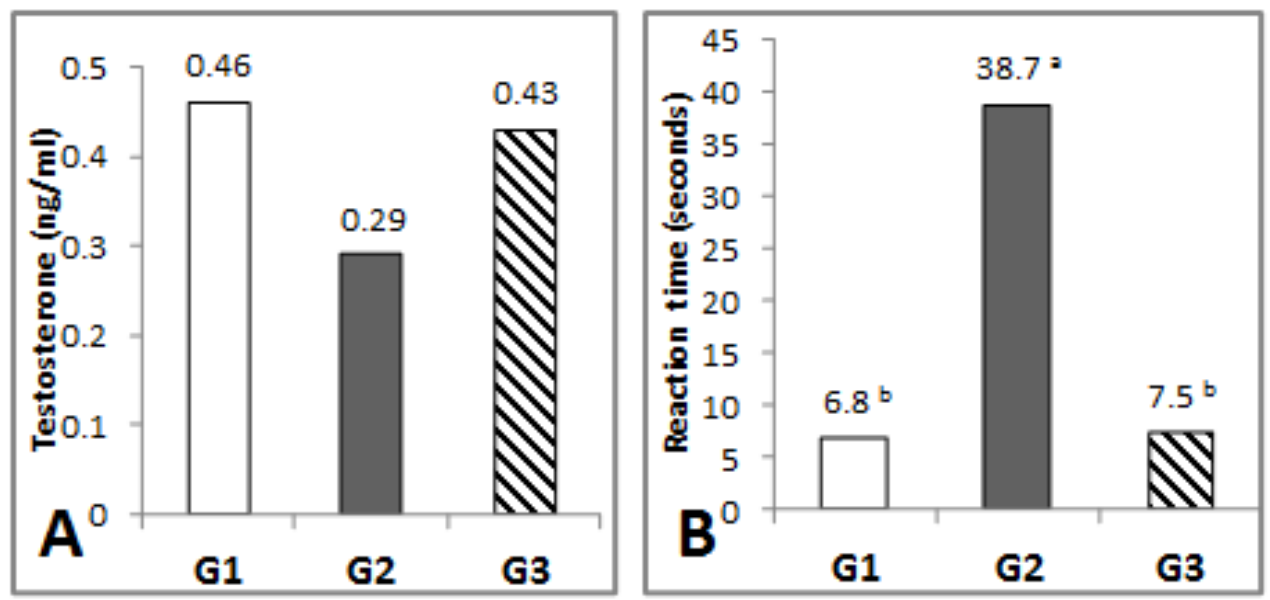

Figure 1. (A and B). Testosterone hormone and reaction time of V-line buck rabbits as affected by drinking saline well water.

a, $b$ Means bearing different superscripts are significantly different $(\mathrm{P}<0.05)$.

G1 $($ Control $)=$ Rabbits drank tap water (301 ppm TDS); G2 =Rabbits drank saline well water (5568 ppm TDS); G3 = Rabbits alternated drank saline well water with tap water weekly. 


\section{EFFECT OF ALTERNATED DRINKING WELL WATER ON RABBITS 143}

The insignificantly differences between the rabbits alternated drank saline water with tap water (G3) and the rabbits drank tap water (G1) in the all semen quality traits may indicated that bucks drinking saline water with tap water (G3) has led to reducing the negative impact of continuous drinking saline water $(\mathrm{G} 2)$ on the semen characteristics and reaction time. On the other hand, this partially improved on semen quality of bucks alternated saline water with tap water (G3) may attributed to the alternation induced enhancement of plasma testosterone and/or may reflect a positive effect on spermatogenic process. The testosterone has been found in addition to his stimulatory effects on the male accessory reproductive organs to have a profound influence on the sperm output (Mann, 1964).

Conclusively, applying alternating water system as a bio-stimulation method could eliminate the drastic effects of continuous drinking well saline water on reproductive performance of rabbits under new reclaimed lands.

\section{REFERENCES}

Ahmed M. M. and Abdel-Rahman M. A. (2004). Effect of drinking natural saline ground water on growth performance, behaviour and some blood parameters in rabbits reared in new reclaimed lands of arid areas in Assiut Governorate. Assiut University Bulletin Environment Research, 7(2), 125-135.

Ahmed, M. H. (1996). Effect of saline drinking water on productive performance of rabbits. M.Sc. Thesis, Faculty of Agric., Zagazig Univ., Egypt.

Amal, M. Hassan (2003). Some physiological and productive effects of promoting growth in rabbits drinking natural saline water. Ph.D. Thesis, Fac. Agric., Cairo Univ., Egypt

Amal, M. Hassan (2013). Semen quality and hematology parameters of white leghorn cocks drinking saline water under hot desert conditions. Egypt. Poult. Sci., Vol

(33) (I): 163-179.

Attia,Y. A., A. E. Abd El-Hamid., A. M. El-Hanoun., M. A. AlHarthi.,G. M. Abdel-Rahman., M. M. Abdella (2015). Responses of the fertility, semen quality, blood constituents, immunity and antioxidant status of rabbit bucks to type and magnetizing water. Ann. Anim. Sci., Vol. 15, No. 2: 387-407 DOI: 10.2478/aoas-2014-0086.

Ayyat, M. S.; Habeeb, A. A. and Bassuny, S. M. (1991). Effect of water salinity on growth performance, carcas traits and some 
physiological aspects of growing rabbits in summer season. Egypt $J$. Rabbit Sci., 1: 21-34.

Abdel-Razik, M. A.; Nwar M. E.; Abdel-Samee A. H. and Nada T. M. C. (1999). Productive performance of male New Zealand White rabbits as affected by water quality. In Proc.: $1^{\text {st }}$ Conf. Indigenous Versus Acclimatized Rabbits. El-Arish, North of Sinai, Egypt. pp. $327-$ 332.

Abdel-Samee, A. M., El-Masry K. A. (1992). Effect of drinking natural saline well water on some productive and reproductive performance of Californian and New Zealand White rabbits maintained under North Sinai conditions. Egyptian J. Rabbit Sci., 2, 1- 11.

Baile, C. A. and McLaughlin, C. L. (1987). Mechanisms controlling feed intake. J. Anim. Sci., 64: 915-922.

Balnave, D. and Yoselewitz, I. (1988). Salinity of drinking water affects egg shell quality. Foodstuffs Journal, 60: 21.

Blom, E. (1950). A 1-min live-dead sperm stain by means of eosin-nigrosin. J. Fertil. Steril., 1: 176-177.

Challies, D. J.; Zeinstra, J. S. and Anderson, M. J. (1987). Some effect of water quality on the performance of high yielding cows in an arid climates. Vet. Rec., 120: 12.

Duncan, D. B. (1955). Multiple range and multiple F-test. Biometrics, 11: $1-42$.

El-Darawany, A. A., Farghaly H. M. (1995). Sequals of using agricultural drainage drinking water for drinking on semen quality and reproductive performance of buck rabbits. Egyptian J. Rabbit Sci., 5(2), 147-156.

El-Darawany, A. A., Farghaly, H. M., Yamani, K. A. and Marai, I. F. M. (1994). Preliminary studies on the effect of using drinking water for drinking on productive traits of rabbits in Egypt. Options Mediterraneennes, 8: 415-424.

Gad, A. E. (1996). Effect of drinking saline water on productive performance of rabbits. M.Sc. Thesis, Faculty of Agriculture, Zagazig University, Zagazig, Egypt.

García-Tomás M.; Tusell LI.; López-Béjar M.; Ramon J.; Rafel O. and Piles M. (2008). Influence of environmental temperature and relative humidity on quantitative and qualitative semen traits of rabbits. 9 th World Rabbit Congress - June 10-13, 2008 - Verona - Italy. 
Graves, C. N. (1978). Semen and its components. In: Salisbury, G. W., Van Demark, N. L. and Lodge, J. R. (eds). Physiology of reproduction and artificial insemination of cattle, 2nd Ed., pp. 247, Freeman, W. H. and Company, San Francisco.

Guyton, A. and Hall, J. E. (1996). Textbook of medical physiology. $6^{\text {th }}$ Ed., W.B. Saunders, Philadelphia, USA.

Habeeb, A. A.; Marai I. F. M.; El-Maghawry A. M. and Gad A. E. (1997). Growing rabbits as affected by salinity in drinking water under winter and hot summer conditions of Egypt. Egyptian J. of Rabbit Sci., 7 (2), 81-94.

Haenlein, G. F. W. (1991). Advances in the nutrition of macro and microelements in goats. Proc. VII ${ }^{\text {th }}$ Reunion Nacional Sobre Caprinocultura, Monterey, Mexico, Oct. 23-25, 290.

Luzi, F.; Maertens L.; Mijtem P. and Pizzi F. (1996). Effect of feeding level and dietary protein content on reaction time and semen characteristics of bucks. $6^{\text {th }}$ World Rabbit Congress, Toulouse, France, 2: 87-92.

Mann, T. (1964). Metabolism of semen: fructolysis and sperm energetics. In: The Biochemistry of Semen and the Male Reproductive Tract. Wiley, New York, USA, pp. 265-307.

Marai I. F. M. and Habeeb A. A. (1994). The effect of salinity of drinking water on farm animals. Chapter 8.inAbDewi I., Axford R. F. E., Marai I. F. M., Omed. H. M. (ed), Pollutionin Livestock Production Systems. Commonwealth Agricultural Bureaux International. PP 119135.

Marai, I.F.M.; Habeeb A. A. M. and Gad A. E. (2005). Tolerance of imported rabbits grown asmeat animals to hot climate and saline drinking water in the subtropical environment of Egypt. J. Anim. Sci., 81, 115-123.

Marai, I. F. M.; Habeeb A. A. M.; Gad A. E. and Mahrose K. H. M. (2010). Rabbits productive, reproductive and physiological traits as affected by drinking saline water: The $6^{\text {th }}$ Inter. Con .on Rabbit Prod. in Hot Clim., Assuit, Egypt, 177-189. A review.

Melrose, D. R. and Laing J. A. (1970). The Characteristics Of Normal Semen. Chap. 4-Fertility and infertility in the domestic animals. Ed. By J.A. Laing Bailliere Tindall and Gassell, London. 
Mocé E.; Lavara R.; Lavara F. and Vicente J. S. (2000). Effect of reproductive rhythm on seminal parameters from a rabbit line selected with high growth rate. In Proc. $7^{\text {th }}$ World Rabbit Congress, Valencia, Spain, Vol. A, 197-201.

Morsy, A. S.; Manal, M. H. Gad- El-Moula; Dooa, O. Othman; Hassan, M. Sobhy; Nagwa A. Ahmed (2016). Blood picture, metabolites, minerals and hormones of rabbits as influenced by alternated drinking saline water. Global Journal of Advanced Research, Vol. 3, Issue-11 PP. 1009-1017.

Muller, R. K. (1995). Toxicological Analysis. Molina press, Leipzig, Germany.

NRC ( 1977). Nutrients and Toxic Substances in Water for Livestock and Poultry. National Academy Science,Washington, D.C.

Pond, W. G.; Chuch, D. C. and Pond, K. R. (1995). Basic animal nutrition and feeding.4th Ed., Wiely and Sons, New York, Chichester, Brisbane, Toronto and Singapore.

Sandford, J. C. (1996). Nutrition And Feeding Of Thedomestic Rabbit. 5th Ed., Blackwell Science.

Smith, J. T. and Mayer, D. T. (1955). Evaluation of sperm concentration by the hemocytometer method. Fertil. Steril., 6: 271-275.

Suckow, M. A. and Douglas, F. A. (1997). The Laboratory Rabbit. CRC Press, Boca Raton, New York.

SAS Institute (2004). SAS User's Guide: Statistics. Release 9.1. SAS Institute Inc., Cary, $N C$.

Veeramachaneni, D. N. R.; Palmer, J. S., and Amann, R. P. (2001). Long-term effects on male reproduction of early exposure to common chemical contaminants in drinking water. Human. Reprod., 16, $979-$ 987.

Yousef, M. I.; Abdallah G. A. and Kamel K. I. (2003 a). Effect of ascorbic acid and vitamin $\mathrm{E}$ supplementation on semen quality and biochemical parameters of male rabbits. Animal Reproduction Sci., 76, 99-111.

Yousef, M. I.; Zeitoun, M. M.; El-Awamry, Z. K. and Ibrahim, A. F. M. (2003 b). Effect of drinking saline well water on blood testosterone, seminal plasma enzymes and reproductive performance of rabbits. Egyptian Journal of Andrology \& Reproduction, 17 (1): 67-78. 
EFFECT OF ALTERNATED DRINKING WELL WATER ON RABBITS 147

\section{تأثير تناوب شرب ماء البئر المالح على الأداء التناسلى للأرانب}

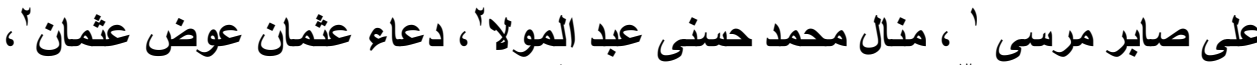

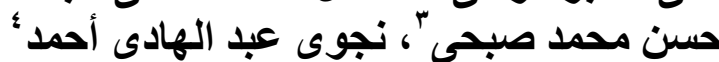

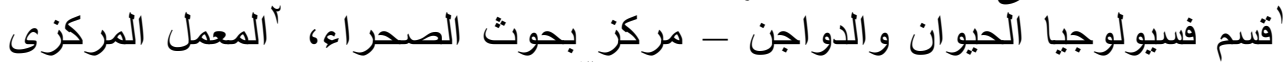

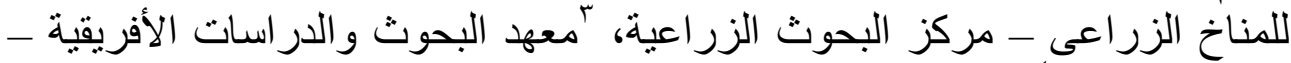

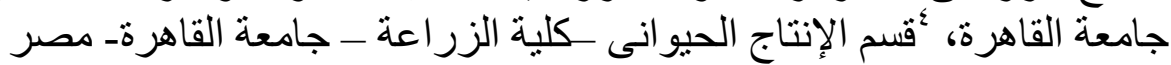

تهدف التجربة إلى در اسـة تأثير شـر ب مـاء البئر المـالح ودر اسـة تنـاوب شـرب الهـاب

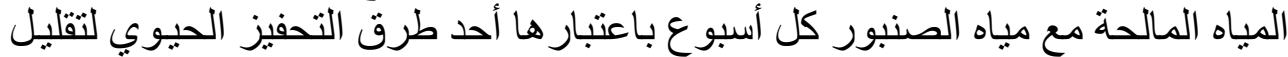

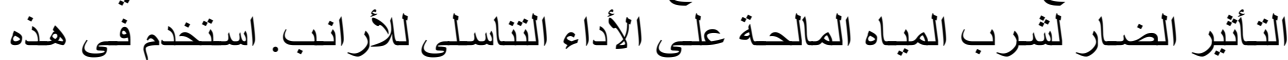

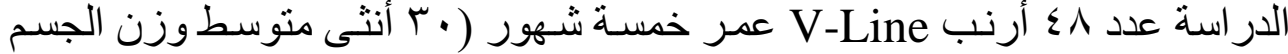

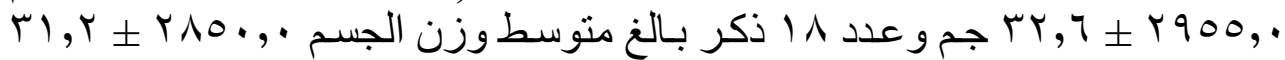

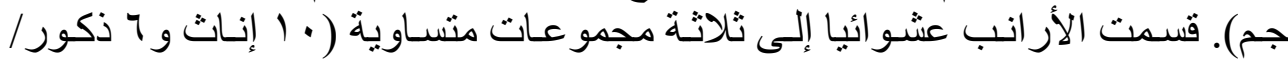

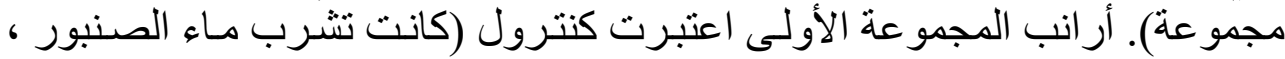

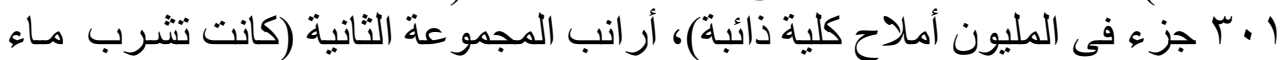
البئر المـالح ،

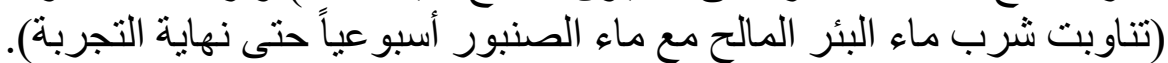

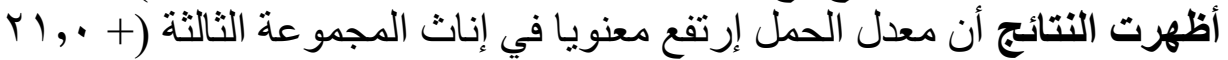

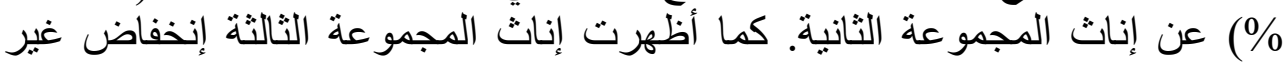

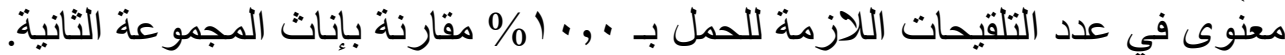

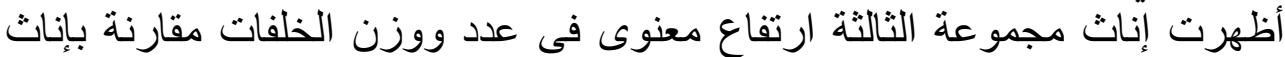

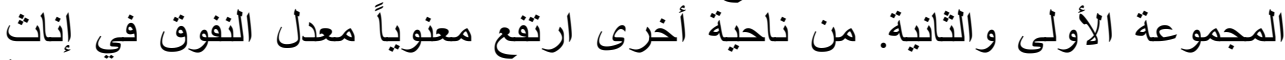

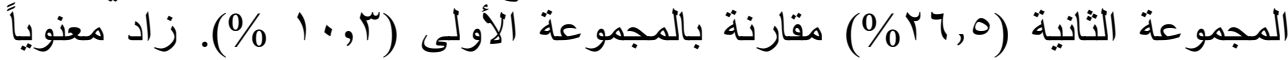

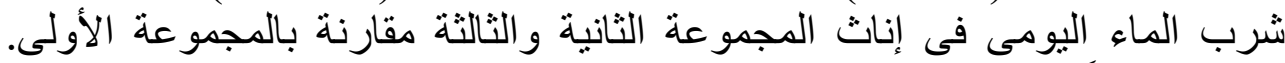
تحسن معنوياً دليل الكفاءة الإنتاجية والتحويل الغذائي فى إناث أر انب المجمو عة الثالثة

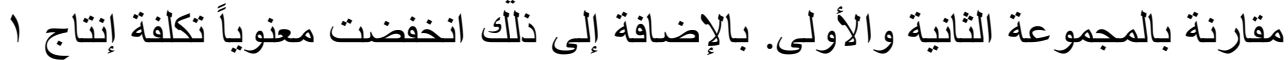

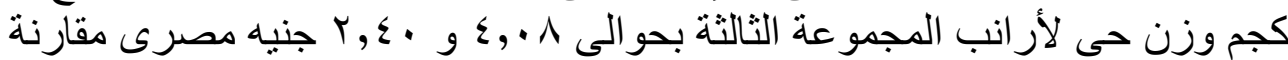
بالمجمو عة الثانية و الأولى على الب التى الته الي.

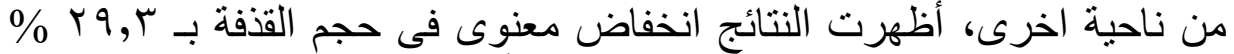

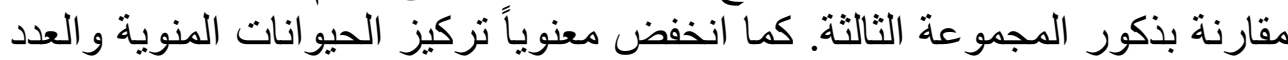

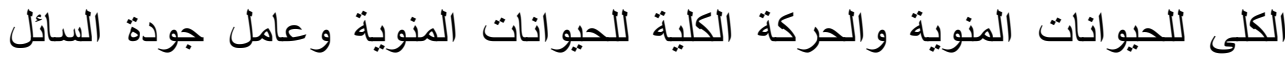
المنوي فى ذكور المجموعة الثانية مقارنة بالمجموعة الكنترول. انخفض معنوياً 
حيوية الحيوانات المنوية في ذكور المجموعة الثانية بمقارنة بالمجموعات الأخرى.

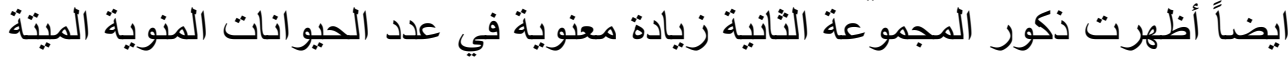

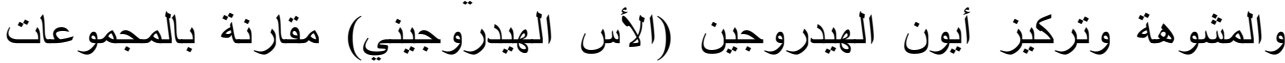

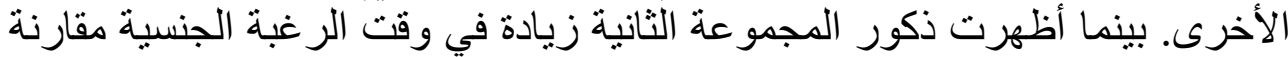

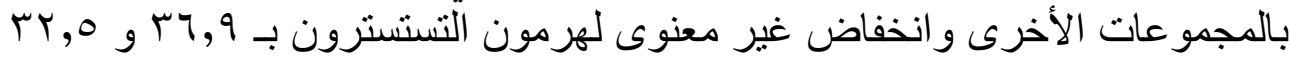

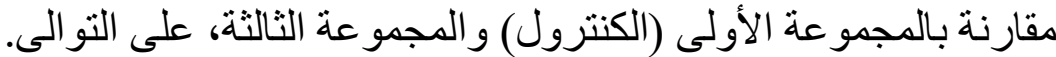

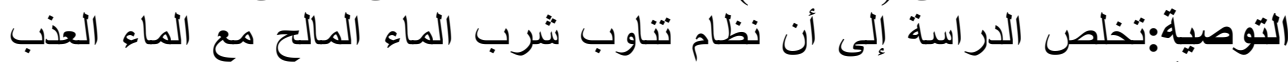

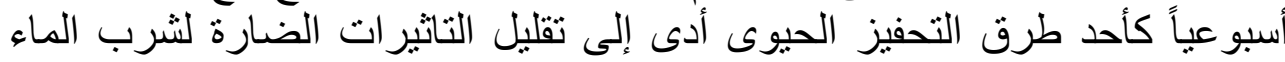

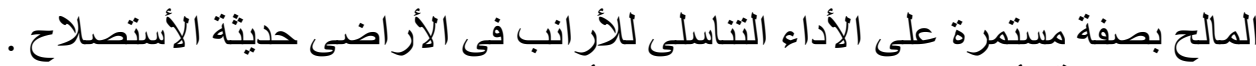

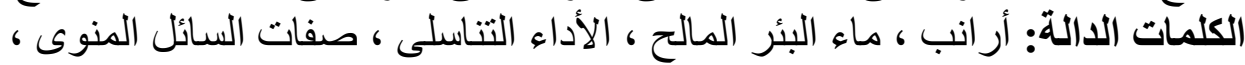

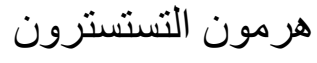

